\title{
BADANIE PRZEWODNOŚCI KOMPLEKSÓW BIAŁKO (BSA) - ENZYM (ACHE) ORAZ WPLYWU PROMIENIOWANIA UV NA ICH STABILNOŚĆ POD KĄTEM ZASTOSOWAŃ W BIOSENSORACH
}

\begin{abstract}
Streszczenie: W pracy zaprezentowano badania przewodności kompleksów BSA- AChE oraz wpływ promieniowania UV na ich stabilność. Na podstawie modeli zaproponowano interpretację jakościowych zmian stabilności kompleksu białko-enzym pod wpływem UV. Potwierdzono analizami, że efekty wywołane przez promieniowanie zależą od czasu naświetlania i są wyraźniejsze dla próbek eksponowanych 90 min niż 30 min.
\end{abstract}

Słowa kluczowe: białko BSA, enzym (AChE), stabilność, przewodność

\section{STUDY ON THE CONDUCTIVITY OF PROTEIN (BSA) - ENZYME(ACHE) COMPLEXES AND THE EFFECT OF UV RADIATION ON THEIR STABILITY FOR APPLICATIONS IN BIOSENSOR}

Summary: This paper presents studies of the conductivity of BSA- AChE complexes and the effect of UV radiation on their stability. Based on the models, an interpretation of the qualitative changes in the stability of the protein-enzyme complex under UV irradiation was proposed. It was confirmed by analyses that the effects induced by radiation depend on irradiation time and are more pronounced for samples exposed $90 \mathrm{~min}$ than $30 \mathrm{~min}$.

Keywords: BSA protein, enzyme (AChE), stability, conductivity

\section{Wstęp}

Zastosowanie biosensorów do monitorowania środowiska [1], jakości żywności [2], diagnostyki medycznej [3] jest obiecującym podejściem ze względu na ich zdolność do szybkiego i taniego oznaczania różnych związków. Wśród całej rodziny biosensorów wyróżnić można biosensory enzymatyczne czyli takie, które zawierają enzym w matrycy biosensora. Sposób unieruchomienia enzymu jest bardzo ważny,

${ }^{1}$ dr inż., Akademia Techniczno-Humanistyczna w Bielsku-Białej, Wydział Budowy Maszyn i Informatyki, awitkowska@ath.bielsko.pl

${ }^{2}$ prof. dr hab. Inż., Akademia Techniczno-Humanistyczna w Bielsku-Białej, Wydział Budowy Maszyn i Informatyki, vmartsenyuk@ath.bielsko.pl 
gdyż wpływa na czułość, selektywność i odporność biosensorów poprzez wpływ na stabilność i aktywność enzymów. Powszechnie stosuje się różne techniki immobilizacji enzymów w tym: absorpcję, wiązanie kowalencyjne oraz łączenie krzyżowe (cross-linking proces), w którym kluczową rolę odgrywa białko BSA (czyli albumina surowicy wołowej (Bovine Serum Albumin) [4]. Biosensory elektrochemiczne oparte na enzymach znalazły powszechnie zastosowanie przy wykrywaniu dużej ilości substancji o znaczeniu biologicznym, takich jak: glukoza[5], mocznik [6], kreatynina [7] arginina [8] acetylocholina [9]. Biosensory tego typu znalazły również zastosowania do oznaczania zanieczyszczeń pasz i żywności. Działanie ich polega na hamowaniu enzymu przez substancje chemiczne dostraczone z zewnatrz. Produkt lub produkty uboczne enzymów mogą być elektroaktywne, co oznacza, że ich aktywność można śledzić za pomocą amperometrii.

Obecnie opracowano szereg biosensorów enzymatycznych opartych na sieciowaniu albuminą surowicy wołowej (BSA) [10], służących do wykrywania związków toksycznych. Enzym Acetylocholinesteraza (AChE) ma bardzo wysoką aktywność katalityczną oraz istnieje szeroka gama związków toksycznych, które hamują ten enzym, dlatego też AChE jest często wykorzystywany do tworzenia biosensorów opartych na analizie inhibicji.

Wśród zagadnień dotyczących biosensorów warto również zwrócić uwagę na problem stabilności komponentów tworzących matryce biosensora.

Celem badania jest ocena wpływu promieniowania UV na stabilność kompleksów białko(BSA) - enzym(AChE) biosensorów elektrochemicznych wykorzystujący w warstwie receptorowej enzym.

Takie biosensory wykorzystywane są w warunkach laboratoryjnych do detekcji patogenów roślinnych czy też zanieczyszczeń [11,12]. Stabilność biosensora jest ważna, gdyż przekłada się ona bezpośrednio na czas użyteczności całego biosensora. Obecnie szuka się nowych rozwiązań poprawiających stabilność biosensora, szuka się również czynników, które tą stabilność osłabiają [13], dlatego też wpisując się w nurt prowadzonych badań wybrano aplikację promieniowania UV na badany kompleks. Badania wpływu promieniowania UV na kompleks BSA-AChE są nowatorskie i stanowią uzupełnienie dotychczasowej wiedzy. W poniższej pracy zostały opisane badanie przewodności kompleksów BSA-AChE oraz wpływu promieniowania UV na ich stabilność pod kątem zastosowań w biosensorach.

\section{Materiały i metody}

Badania przeprowadzono dla wodnych roztworów substancji: białka albuminy wołowej (Bovine Serum Albumin (BSA)) oraz enzymu acetylcholinesteraza (AChE). Odczynniki pochodziły z firmy Sigma-Aldrich Chemie, Niemcy.

W eksperymencie użyto wody zdemineralizowanej KPL2/10/07/01/210753. Do badań wykorzystano Acetylocholinesterazę w formie proszku (C3389-500uN, Lot \#SLCC7974, TypVI-S lyophized powder, 200-100 units/mg protein).

Za pomocą specjalnie skonstruowanego stanowiska pomiarowego składającego się z konduktometru (model CC-401) wraz z elektrodą, naczynia pomiarowego oraz z komputera, wykonano badania przewodności w czasie dla kompleksów: BSAAChE.

Objętość badanego białka wynosiła $2 \mathrm{ml}$, stężenie $(2 \mathrm{mg} / \mathrm{ml})$. Do wodnego roztworu proteinowego dodawano kolejno różne objętości enzymu $(0,1 \mathrm{ml}, 0,2 \mathrm{ml}, 0,3 \mathrm{ml})$ 
o stężeniu $(2 \mathrm{mg} / \mathrm{ml})$. Badano wpływ enzymu na przewodność białka. W przeprowadzonym eksperymencie wybrano stężenie enzymu $2 \mathrm{mg} / \mathrm{ml}$ ze względu na optymalne możliwości pomiarowe. Badania mają charakter wstępny, planowane są kolejne eksperymenty $\mathrm{z}$ użyciem enzymu w różnych stężeniach i różnych objętościach. Eksperyment rozpoczęto od wykonania pomiarów przewodności roztworu białka i enzymu. Następnie badano przewodność kompleksów białko enzym. W eksperymencie uwzględniono zmianę stężenia roztworu pod wpływem dodania enzymu. Badania były prowadzone w temperaturze $21^{\circ} \mathrm{C}, \mathrm{pH}=6$ dla badanego kompleksu. Kolejnym etapem eksperymentu były badania kompleksów BSA-AChE za pomocą dwuwiązkowego spektrometru firmy UV/Vis (Halo DB-20R) Dynamika. Zebrano widma absorpcyjne w zakresie $240-310 \mathrm{~nm}$. Zakres dobrany był w ten sposób aby można było śledzić zmiany w widmie pochodzące od występujących w kompleksie aminokwasów aromatycznych: tyrozyna (Tyr), fenyloalanina (Phe) i tryptofan (Trp).

Kolejno dla kompleksu BSA-0,3 ml AChE wykonano naświetlania promieniowaniem UV (Rys 1)

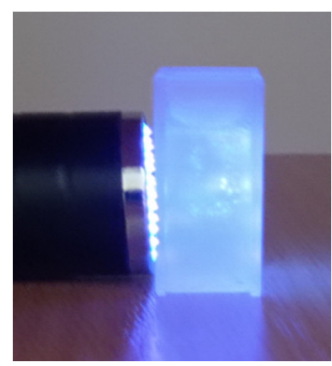

Rysunek 1. Aplikacja promieniowania UV na kompleks BSA-AChE

W tym celu badany kompleks podzielono na 3 próbki. Próbka pierwsza była kontrolą (bez ekspozycji na pole), próbka 2 to próbka eksponowana na promieniowanie UV w czasie 30 min w pierwszym dniu trwania eksperymentu, próba 3 to próbka eksponowana na promieniowanie UV w czasie 90 min w pierwszym dniu trwania eksperymentu.

Eksperyment wykonano w 3 niezależnych seriach pomiarowych, każdy pomiar w pojedynczej serii wykonano trzykrotnie. Otrzymane błędy statystyczne nie przekraczały 5\%. Badano zmiany stabilności kompleksów pod wpływem aplikowanego promieniowania w czasie 12 dni.

Czas trwania eksperymentu (12dni) był podyktowany denaturacją białka BSA wraz z czasem. Zakres 12 dni był również konsekwencją wcześniej prowadzonych badań nad zmianami konformacyjnymi BSA wraz z czasem

\section{Rezultaty i dyskusja}

Rysunek 2 (Rys 2) przedstawia zmianę przewodności wraz z czasem po dodaniu różnej objętości enzymu. Na rysunku cyfrą 1 zaznaczono moment dodania $0,1 \mathrm{ml}$ enzymu AChE do BSA, cyfrą 2 zaznaczono dodanie 0,2 $\mathrm{ml}$ AChE, a cyfrą 3 zaznaczono dodanie $0,3 \mathrm{ml}$ AChE.

Widać wyraźne zmiany w badanej przewodności po dodaniu enzymu. Fakt ten może świadczyć o gwałtownej reakcji chemicznej pomiędzy białkiem a enzymem, która 
zobrazowana jest poprzez wzrost przewodności i która prowadzi do tworzenia się kompleksów pomiędzy BSA a enzymem.

Zaobserwowany wzrost przewodności zależny jest od ilości dodanego enzymu. I tak widać, że w przypadku dodania $0,1 \mathrm{ml}$ enzymu zmiana jest mniejsza niż w przypadku dodania enzymu $0,3 \mathrm{ml}$.

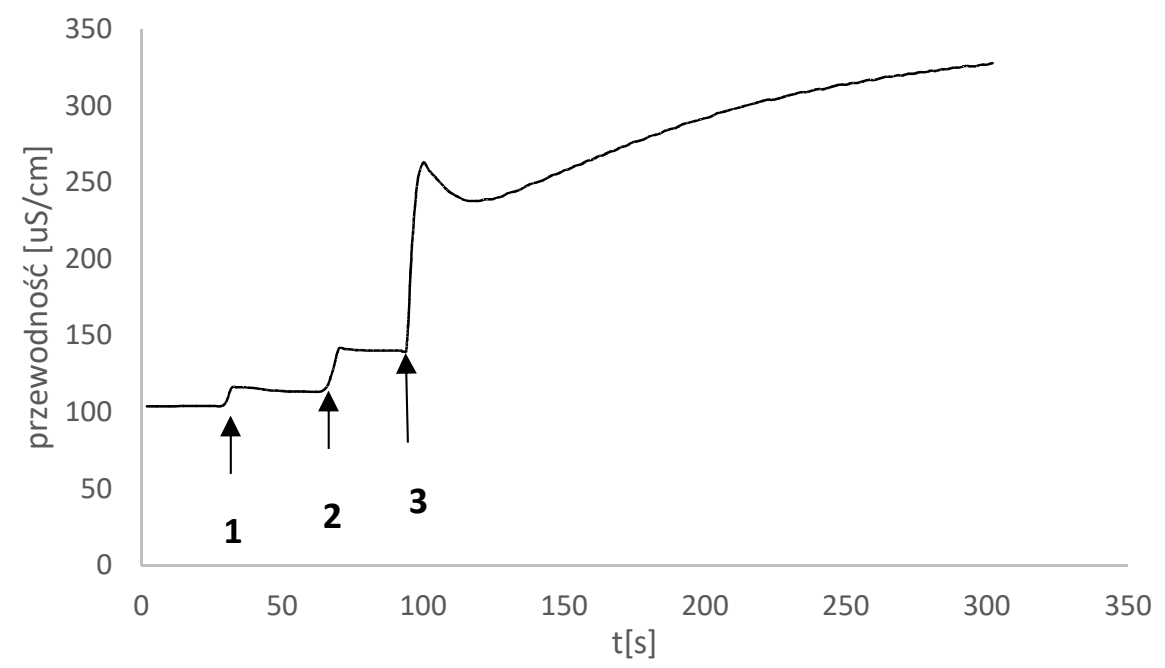

Rysunek 2. Zmiany przewodności w czasie w wyniku tworzenia kompleksów BSA+AChE. Nagłe zmiany (skoki przewodności) wskazują miejsca dodania enzymu

Skok pierwszy (1) dla BSA+0,1 AChE, skok drugi (2) dla BSA+0,2 AChE, skok trzeci (3) dla BSA+0,3 AChE

Rysunek 3 (Rys 3) przedstawia widmo UV-Vis kompleksów białko (BSA) + enzym (AChE). BSA+ 0,1 ml AChE (krzyżyki), BSA+0,2 ml AChE (puste kwadraty), $\mathrm{BSA}+0,3 \mathrm{ml}$ AChE (pełne kwadraty).Widoczny jest obły pik absorpcyjny BSA, w którym maksimum absorpcji w 277 mn pochodzi od aminokwasów aromatycznych występujących w proteinie takich jak: tyrozyna (Tyr), fenyloalanina (Phe), czy tryptofan (Thr). Przyglądając się wartości absorpcji w piku 277nm widać, że wartość ta jest większą dla białka $\mathrm{z}$ małą ilością dodanego enzymu BSA+0,1 ml AChE (krzyżyki) niż dla białka z dodaniem większej ilości enzymu (BSA+0,3 AChE).

Można zatem wnioskować, że dodanie większej ilości enzymu $(0,3 \mathrm{ml})$ bardziej stabilizuje białko niż dodanie $0,1 \mathrm{ml}$.

Najprawdopodobniej większa ilość enzymu zapobiega procesowi denaturacji białka, który związany jest z rozfałdowywaniem się łańcucha polipeptydowego i wzrostem absorpcji. Również oddziaływania van der Waalsa w białku po dodaniu enzymu są mocniejsze, $w$ związku $\mathrm{z}$ tym reakcja białka $\mathrm{z}$ grupami hydrofobowymi rozpuszczalnika zachodzi wolniej [14]. Na rysunku zaznaczono także minimum w 251nm, które będzie użyteczne przy dalszych analizach, które zostaną przeprowadzone w oparciu o modele 


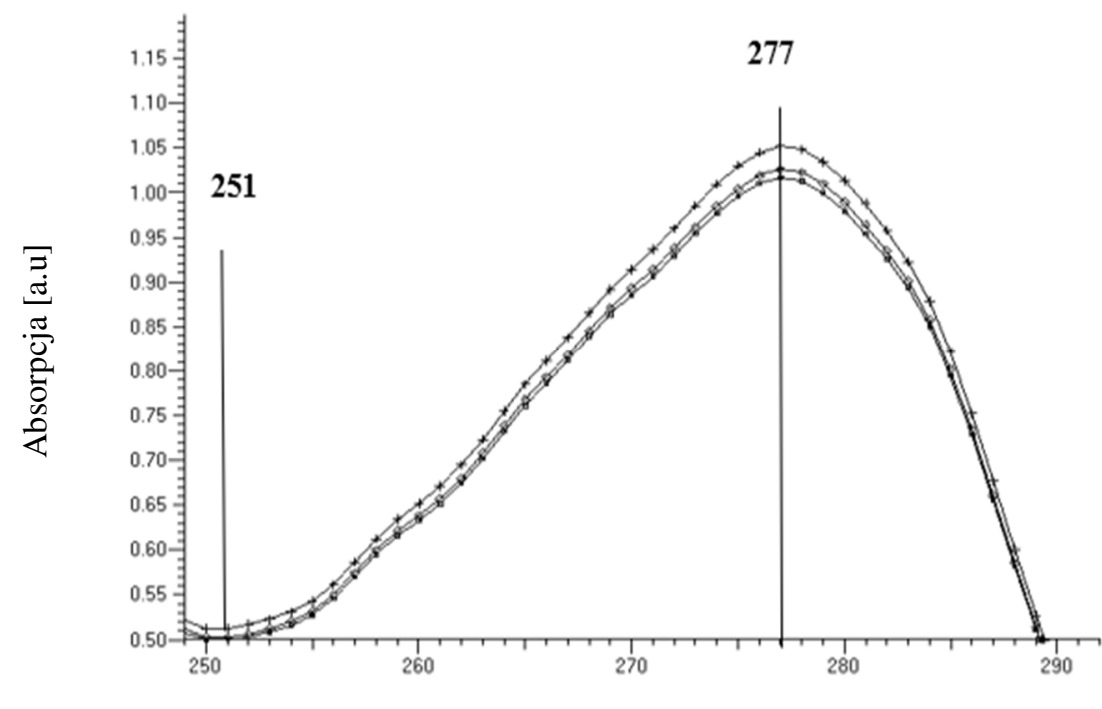

$\lambda[\mathrm{nm}]$

Rysunek 3. Widmo UV-Vis kompleksów BSA + enzym (AChE). BSA+0,1 AChE (krzyżyi), BSA+0,2AChE (puste kwadraty), BSA+0,3 AChE (petne kwadraty)



Rysunek 4. Widmo UV-Vis dla kompleksów BSA+0,3 AChE, promieniowanych UV w czasie 30 min (petne kwadraty) oraz 90 min (linia ciagta) w 12 dniu trwania eksperymentu 
Rysunek 4 (Rys 4) przedstawia. Widmo UV-Vis dla kompleksów BSA+0,3 ml AChE, eksponowanych na promieniowanie UV w czasie 30 min (pełne kwadraty) oraz 90 min (linia ciągła) w 12 dniu trwania eksperymentu. Widać większą absorpcję w piku pochodzącym od próbek poddanych działaniu promieniowania 90 min niż w piku pochodzącym od próbek poddanych działaniu promieniowania $30 \mathrm{~min}$.

Zaobserwowano, że im dłuższa ekspozycja na pole elektromagnetyczne z zakresu UV, tym denaturacja w kompleksie zachodzi szybciej. Zmiany odległości w łańcuchu polipeptydowym skutkują zmianami oddziaływań pomiędzy aminokwasami. Trzeciorzędowa struktura białka zostaje zaburzona, co skutkuje spadkiem jego stabilności.

Następuje wzrost konformacji helisy z jednoczesnym spadkiem konformacji beta [15]. Proces ten prowadzi do utraty proteinowego szkieletu co w konsekwencji prowadzi do spadku stabilności struktury.

Widać, że wydłużona ekspozycja na pole elektromagnetyczne z zakresu UV wzmacnia ten efekt

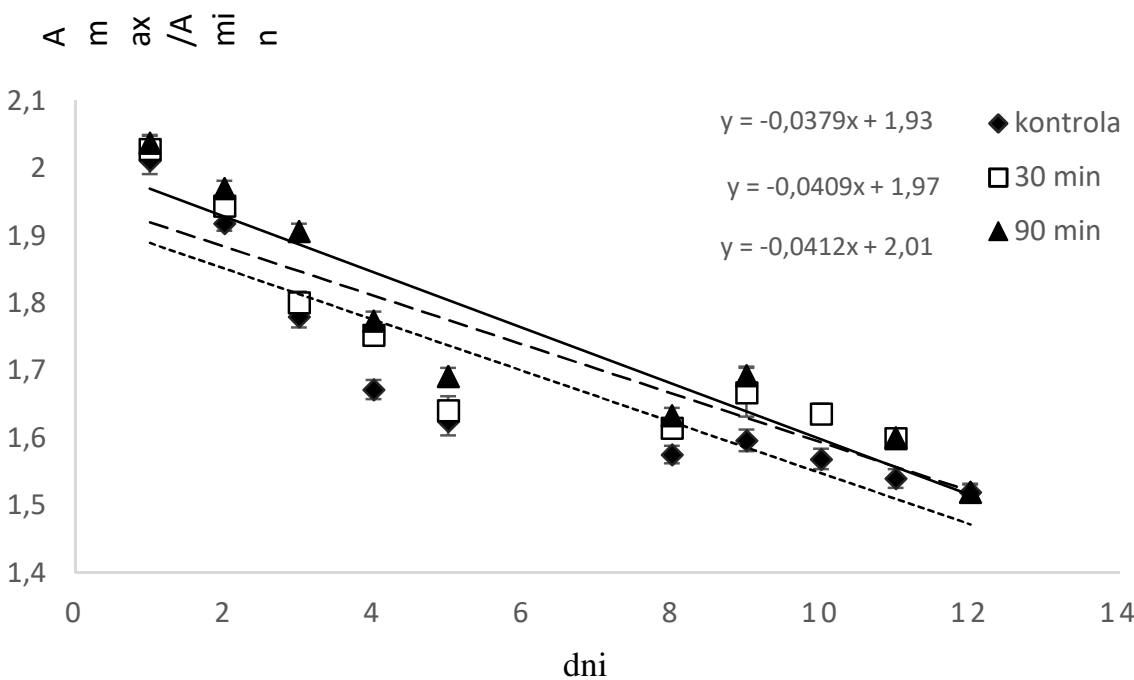

Rysunek 5. Zmiany parametru Amax/Amin w kolejnych dniach eksperymentu dla kontroli ( petne kwadraty), kompleksu BSA+enzym (0,3 AChE) promieniowanego 30 min (puste kwadraty), kompleksu BSA+enzym (0,3 AChE) promieniowanego 90min (petne trójkąty)

Do analizy stabilności kompleksu BSA-enzym wykorzystano maksimum absorpcji w $277 \mathrm{~nm}$ oraz lokalne minimum rozważane w zakresie długości fali przy $251 \mathrm{~nm}$ (Rys 3). W tym celu wykorzystano model zmian konformacji białka zaproponowany przez A. Michnik [16]. Zgodnie z założeniami tego modelu obliczono parametr (Amax/Amin). Stosunek absorbcji przy lokalnym maksimum (Amax przy $\mathrm{k}=277 \mathrm{~nm}$ ) i lokalnym minimum (Amin przy $\mathrm{k}=251 \mathrm{~nm}$ ) w zakresie 250-280 nm został wybrany na podstawie badań Artyukhova [17]. Według nich, stosunek 
(Amax/Amin) może być uważany za wskaźnik zmian strukturalnych. W pracy zasugerowano, że obniżenie tego stosunku związane jest z procesami destrukcyjnymi w aminokwasach aromatycznych białka .

Na rysunku 5 (Rys 5) przedstawiono zmianę parametru (Amax / Amin) w kolejnych dniach eksperymentów. Zmniejszanie się parametru Amax / Amin z czasem, zgodnie $\mathrm{z}$ założeniami modelu, sugeruje procesy destrukcyjne $\mathrm{w}$ aminokwasach aromatycznych białka. Proces ten zachodzi zarówno w próbkach napromieniowanych 30 min, jak i 90 min. O tempie zachodzących zmian można wnioskować na podstawie parametru ,a” trendu liniowego $(\mathrm{y}=\mathrm{ax}-\mathrm{b})$. Parametr ten wskazuje na dynamikę zachodzących zmian. Dla próbek napromieniowanych 30 min wartość parametru a wynosi $(a=-0,0409)$, podczas gdy dla próbek napromieniowanych 90 min wartość ta wynosi $(\mathrm{a}=-0,0412)$

Widać, więc, że szybsze zmiany destrukcyjne w aminokwasach aromatycznych białka zachodzą w próbkach dłużej napromienianych, tj. 90 min, niż w próbkach napromieniowanych 30 min. Można zatem stwierdzić, że im dłuższa ekspozycja na promieniowanie UV, tym szybciej zachodzą zmiany destrukcyjne w białku.

Można zauważyć, że dłuższa ekspozycja na promieniowanie UV powoduje destabilizację kompleksów BSA+ enzym $(A C h E)$ i jest ona proporcjonalna do czasu ekspozycji. Zmiany stosunku Amax/Amin pod wpływem promieniowania UV mogą być związane $\mathrm{z}$ destrukturyzacją konformacyjną cząsteczki albuminy, w tym reorganizacją regionów, w których znajdują się aminokwasy aromatyczne (tryptofan i tyrozyna). Utrata stabilności kompleksu pod wpływem promieniowania UV jest proporcjonalna do długości czasu ekspozycji na promieniowanie.

Rys 6 prezentuje względne różnice procentowe pomiędzy kompleksem BSA-AChE promieniowanym 90 minut, a kompleksem BSA-AChE promieniowanym 30 minut

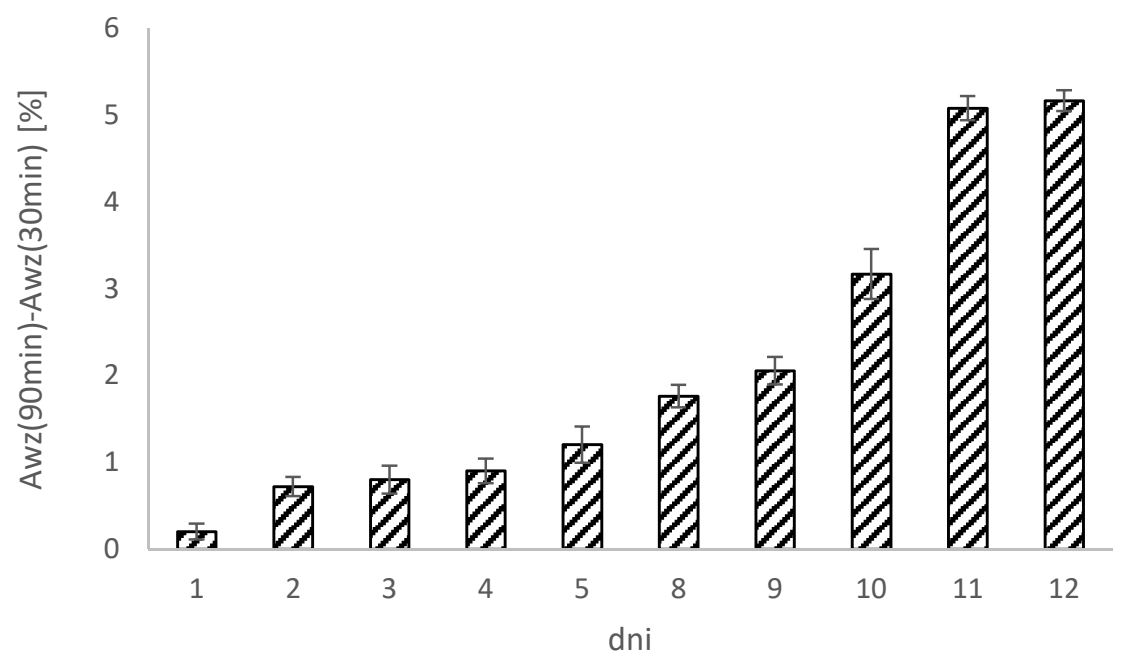

Rysunek 6. Względne różnice procentowe pomiędzy kompleksem BSA-AChE poddanym działaniu promieniowania 90 minut, a kompleksem BSA-AChE poddanym działaniu promieniowania 30 minut 
Widać, że w pierwszych dniach trwania eksperymentu różnice te są nieznaczne, jednak wraz z upływem czasu różnice pomiędzy BSA-AChE poddanym działaniu promieniowania 90 minut, a kompleksem BSA-AChE poddanym działaniu promieniowania 30 minut stają się bardziej znaczące. W 11 i 12 dniu eksperymentu różnice te wynoszą ponad 5\%.

\section{Podsumowanie}

W pracy za pomocą specjalnie skonstruowanego układu pomiarowego dokonano pomiarów przewodności kompleksów BSA-Enzym (AChE).

Wykazano gwałtowne zajście reakcji chemicznej po dodaniu do czystego białkaenzymu. Dynamika reakcji była tym większa im większa ilość enzymu.

Druga część przeprowadzonych eksperymentów była skupiona na badaniu stabilności kompleksów BSA-Enzym(AChE) po aplikacji promieniowania UV z ekspozycją 30 min oraz 90 min.

Na podstawie modeli zaproponowano interpretację jakościowych zmian stabilności kompleksu BSA-enzym pod wpływem ekspozycji na promieniowanie UV (30min i $90 \mathrm{~min})$.

Wykazano, że badane czynniki wpływają na stabilność badanej substancji, obniżając stabilność kompleksu. Zaobserwowano i potwierdzono analizami, że efekty wywołane przez promieniowanie UV zależą oraz czasu naświetlania.

Większy wpływ zaobserwowano dla próbek eksponowanych na pole elektromagnetyczne $90 \mathrm{~min}$ niż dla próbek poddanych działaniu promieniowania $30 \mathrm{~min}$.

Otrzymane efekty związane są ze zmianami w lokalnym otoczeniu uporządkowanego łańcucha polipeptydowego, zmianami odległości w łańcuchu polipeptydowym na skutek mniejszego oddziaływania van der Waalsa a także osłabieniem stabilności białka pod wpływem rozpuszczalnika oraz reorganizacją cząsteczek wody w roztworze pod wpływem promieniowania UV.

\section{Podziękowania}

Praca została współfinansowana dzięki Eropean Union Erasmus + Programme for Education under KA2 grant (project no 2020-1-PL01-KA203-082197) 'Innovations for Big Data in a Real World" 


\section{LITERATURA}

1. JUSTINO C., DUARTE A., ROCHA-SANTOS T.: Recent Progress in Biosensors for Environmental Monitoring: A Review, 17 (2017), 2918.

2. GE L., LIU Q., HAO N., KUN W.: Recent developments of photoelectrochemical biosensors for food analysis: J. Mater. Chem. B,7 (2019),7283-7300.

3. KLOS-WITKOWSKA A.: Enzyme-Based Fluorescent Biosensors and Their Environmental, Clinical and Industrial Applications: Pol. J. Environ. Stud. 24(2015),19-25.

4. SASSOLAS A., BLUM L., LECA-BOUVIER B.: Immobilization strategies to develop enzymatic biosensors: Biotechnol Adv.30 (2012), 489-511.

5. UNNIKRISHAN B., PALANISOMY S., CHEN S.: A simple electrochemical approach to fabricate a glucose biosensor based on graphene-glucose oxidase biocomposite: Biosensos.Bioelectron 39 (2013), 70-75.

6. TYAGI M., TOMER M, GUPTA V.: NiO nanoparticle-based urea biosensor. Biosens.Bioelectron.41 (2013) 110-115.

7. PUNDIR S., YADAR S., KUMAR A.: Creatine sensors: TrAC-Trends Anal.Chem 50 (2013), 42-52.

8. SHELIAKINA M., ARKHYPOVA V., SOLDATKIN O., SAIAPINAO., AKATA B.,DZYADEWYCH.:Unrease-based ISFET biosensor for argininę determination: Talanta 121 (2014), 18-23.

9. HOU S., QU Z., CHEN Q., Wu B.:Amperometric acetylocholine biosensor based on self-assembly of gold nanoparticle and acetylocholinesteraze on the sol$\mathrm{gel} /$ multiwalled carbon nanotubes/choline oxidase composite-modified platinum electrode: Biosens. Bioelectron 33 (2012), 44-49.

10. ISMAIL F., ADELOJU S.: Comparison of Single Layer and Bilayer Biosensors Based on Crosslinking of Penicillinase for Potentiometric Detection of Penicillin in Milk and Antibiotics: Electroanalysis 27 (2015), 1523-1531.

11. ŁABAŃSKA M., PRZEWODOWSKI W.: Biosensory - nowoczesne narzędzia analityczne detekcji patogenów roślinnych: Biuletyn Instytutu Hodowli i Aklimatyzacji roślin 290 (2020):33-42.

12. DĄBROWSKA K., MATEJCZYK M.: Podstawy konstrukcji biosensorów do badań biotechnologicznych :Kosmos 69 (2020) 333-343.

13. REYS-DE-CORCUERA L, OLDSTAD H., GARCIA-TORES R.: Stability and Stabilization of Enzyme Biosensors: The Key to Successful Application and Commercialization: Annual Review of Food Science and Technology 9 (2018), 293-322.

14. KLOS-WITKOWSKA A., MARTSENYUK V: A meta-analysis of the influence of the external conditions on the biosensor receptor layer component stability: Acta Biochimica Polonica 68 (2021), 5591.

15. TAKEDA K., WADA A., YAMAMOTO K., MORIYAMA Y, AOKI K.: Conformational change of bovine serum albumin by heat treatment.: J Protein Chem 8 (1989) 653-659. 
16. MICHNIK A., MICHALIK K., DRZAZGA Z.: Stability of Bovine Serum Albumin at different pH, Journal of Thermal Analysis and Calorimetry 80(2005), 399-406.

17. ARTYUKOV V., PANTYAVIN G., VASHANOV G.: Vacuum-UV-RadiationInduced Structural-Functional Changes in Serum Albumin Molecules, Journal of Applied Spectroscopy 68 (2001), 291-298. 